\title{
Prognostic Factors in Patients with Congestive Heart Failure
}

\author{
Humberto Villacorta, Evandro Tinoco Mesquita
}

Rio de Janeiro and Niterói, RJ - Brazil

The natural history of congestive heart failure (CHF) was initially described in the Framingham Heart Study, carried out in the US city of Framingham, Massachusetts, in which 5,209 individuals were randomly selected and followed for four decades (1949 to 1987) ${ }^{1}$. In 1971, the descendents of this initial population and their respective spouses (5,135 individuals) were also included in the study and, in 1993, the evolutional data of this cohort study of 10,344 participants were published ${ }^{2}$. The survival rate in five years was $25 \%$ for men and $38 \%$ for women; this survival rate is similar to that observed in patients with some types of cancer, such as lung cancer, for example ${ }^{3}$.

It is estimated that in the US almost four million people have $\mathrm{CHF}$ and that 700,000 new cases occur every year ${ }^{4}$. In addition to the high prevalence, there is another factor of concern. There is evidence that the number of hospital admissions due to CHF has increased in the last two decades. According to North American statistics, the number of hospital admissions of individuals older than 65 years and whose main diagnosis was CHF increased from 7.5 per 1,000 in 1986 to 16.3 per 1,000 in $1989^{2}$.

These data cause CHF to be regarded as a public health problem throughout the world. The high morbidity and mortality show that the current treatment is still unsatisfactory. On the other hand, economic resources are limited and every strategy should be well assessed to avoid wasting. Therefore it is very important to identify the individuals with poor prognosis who can eventually benefit from aggressive management.

This manuscript discusses prosent issues of the main prognostic factors used in the assessment of patients with CHF. Some have recognized value and are used frequently in the clinical practice. Others have a controversial or not well-established value, as we will see below.

\section{The role of gender}

$\mathrm{CHF}$ is more common in men than in women, but the role of sex as a prognostic factor is not clear. In the Framin-

Hospital Pró-Cardíaco, Rio de Janeiro and Universidade Federal Fluminense, Niterói Mailing address: Humberto Villacorta - Rua Raimundo Correa, 23/601 - 22040040 - Rio de Janeiro, RJ - Brazil gham study ${ }^{1,2}$, two years after the diagnosis of CHF, $37 \%$ of the men and $38 \%$ of the women were deceased. Six years thereafter, however, there was a clear difference favoring women, whose mortality rate was $67 \%$ compared to $82 \%$ in men. According to Hermann and Greenberg ${ }^{5}$, however, it is not known if this reflects a difference in the natural history of the disease or if it results from the influence of the underlying etiology or from gender-dependent res-ponse to treatment. Schocken et $\mathrm{al}^{6}$, in another population study, also found smaller mortality in women. In Chagas' disease, the male patients, who have greater impairment in ejection fraction (EF), also have the poorest prognosis compared to women $^{7,8}$.

In other studies, the opposite was observed. In the prevention substudy of the SOLVD investigators ${ }^{9}$, women, who comprised $26 \%$ of the total patient population, had an annual mortality rate significantly higher than that of men (22\% compared to $17 \%$ ) and a higher rate of hospitalization due to CHF (33\% compared to $25 \%$ ). In the substudy that assessed the treatment with enalapril ${ }^{10}$, in the same project, only $15 \%$ of the participants were women and there was no difference in mortality rate between the genders.

Adams et al ${ }^{11}$ evaluated the prognostic value of gender in relation to etiology of $\mathrm{CHF}$ and reported a higher survival rate in women with CHF caused by nonischemic heart disease than in men with or without coronary artery disease (CAD). When CHF in women was caused by ischemic heart disease, however, there was no significant difference between genders.

In a multicenter Italian study ${ }^{12}$ of idiopathic dilated cardiomyopathy, women showed more advanced disease than men, in regard to symptoms and left ventricle (LV) dimensions. There was, however, no statistically significant difference in regard to mortality, even though there was a tendency toward a poorer prognosis in females.

A limiting factor for establishing the role of gender in the prognosis of CHF is the small number of women usually included in the studies. Lindenfeld et al ${ }^{13}$ suggest that this happens because of the higher proportion of diastolic CHF, in relation to systolic dysfunction, in women. In large clinical trials the selection of patients is usually based on EF, in an attempt to include those with severe systolic dysfunction. The number of women with severe systolic dysfunction is 
much smaller than that of men. According to these same authors, this would also explain the better prognosis for women observed in the Framingham study.

An ongoing study (BEST study) ${ }^{5}$ that evaluates the effects of the beta-blocker bucindolol is the first study of CHF survival designed to include a great number of women, so that an accurate statistical analysis can be made of the relation between gender and prognosis and the therapeutical response ${ }^{5}$.

\section{Age}

Advanced age, independent of gender and race, is related to a poorer prognosis. In the Framingham Study, there was an increase in mortality with the increase in age at the moment of diagnosis of CHF. The increase was $27 \%$ and $61 \%$ for each decade of life, in men and women, respectively ${ }^{2}$.

In the SOLVD study ${ }^{14}$, the annual mortality in individuals from 21 to 55 years of age was $16.6 \%$, increasing to $38.4 \%$ in those older than 76 years. The second Veterans' study ${ }^{15}$, however, did not show any relation between age and survival, but the subgroups may have been too small to detect it ${ }^{5}$.

\section{Presence of comorbidity}

Many diseases can occur in association with CHF, worsening its prognosis. The most studied ones are hypertension and diabetes mellitus. Hypertension triples the risk of developing $\mathrm{CHF}^{6}$. In addition, persistent hypertension in a patient with $\mathrm{CHF}$ worsens the cardiac performance due to vasoconstriction and, therefore, should be aggressively treated ${ }^{5}$.

Diabetic cardiomyopathy was described as an entity in the $70 \mathrm{~s}^{16}$, and there is evidence that its incidence has increased ${ }^{2}$. Independently from the risk of developing $\mathrm{CAD}$, diabetes increases the risk of developing CHF, and this risk is at least double in women than in men ${ }^{6,17}$. The risk of CHF is increased five times when hypertension is associated with diabetes ${ }^{5}$. Data of mortality directly related to these entities are difficult to analyze because of the frequent association of other affections, such as atherosclerotic disease and stroke ${ }^{5}$.

Both renal and hepatic failure can worsen the prognosis of CHF because they limit the use of some medications angiotensin-converting enzyme inhibitor (ACEI), for example - and impair the therapeutic response ${ }^{5}$. In a metanalysis by Golper ${ }^{18}$, involving more than 60 patients in peritoneal dialysis, the survival rate in one and two years was only $37 \%$ and $15 \%$, respectively. In another study ${ }^{19}$ carried out in 35 patients with CHF being treated with continuous hemofiltration, the mean survival rate was 10 months.

Other associated disorders, such as pulmonary hypertension of any etiology, tobacco use, alcohol consumption, and pulmonary diseases are related to a worse $\operatorname{prognosis}^{5,20}$.

\section{Etiology of congestive heart failure}

The etiology of CHF can sometimes influence prognosis. The presence of CAD as a cause of CHF is questioned as a factor worsening the course of the disease. So far, there is no agreement in regard to this question. Studying individuals with CAD, Franciosa et al $^{21}$ found a mortality rate of $46 \%$ and $69 \%$, for one and two years, respectively. For patients with idiopathic dilated cardiomyopathy, the rate was significantly smaller, $23 \%$ and $48 \%$, respectively.

In a study carried out in Japan ${ }^{22}$, patients with CAD had a worse survival rate in five years than those with idiopathic dilated cardiomyopathy (35\% to $40 \%$ ). Other authors ${ }^{23-25}$ also found a worse prognosis in patients with ischemic cardiomyopathy. Bart et $\mathrm{al}^{25}$, in a recent study on patients who underwent coronary angiography, not only demonstrated that the ischemic etiology was an independent predictor of mortality, but also observed that the extension of CAD was a stronger predictor than the presence or absence of ischemic heart disease.

In the Veterans' study ${ }^{26}$ and in the studies of Cohn et $\mathrm{al}^{27}$ and Parameshwar et $\mathrm{al}^{28}$, the presence of CAD was not related to worse prognosis.

Some diseases, such as hypertrophic cardiomyopathy ${ }^{29}$, hemochromatosis ${ }^{5}$, endomyocardial fibrosis ${ }^{30}$, Chagas' cardiomyopathy ${ }^{31}$, and amyloidosis, ${ }^{5}$ have a significantly poorer prognosis when they evolve with $\mathrm{CHF}$. Amyloidosis has a mortality rate of $100 \%$ in two years, after the onset of symptoms ${ }^{5,32}$, and the prognosis is worse in those with restrictive cardiomyopathy ${ }^{33}$.

\section{Functional class}

The severity of the symptoms caused by CHF seems to be related to mortality ${ }^{10,14,21,34,35}$. The classification most used to quantify the symptoms is that of the New York Heart Association (NYHA). In the SOLVD study ${ }^{10}$, patients in functional class (FC) IV had a mortality of $64 \%$ during a mean follow-up of 41.4 months compared to patients in FC III, II, and I, whose mortality rates were $51 \%, 35 \%$, and $30 \%$, respectively.

The NYHA classification, despite being practical and widely known and a determinant of prognosis, is criticized by some authors ${ }^{5}$. It not always correlates with the degree of ventricular dysfunction or with objective measures of exercise capacity ${ }^{26,36,37}$. Therefore, we can find patients with preserved systolic function and with significant diastolic alterations that, despite severe symptoms of $\mathrm{CHF}$, have a long-term prognosis better than those with systolic dysfunction ${ }^{22,38,39}$. It is not uncommon to find patients with severe systolic dysfunction of the LV and mild symptoms.

Another less known but more reproducible classification is the Specific Activity Scale ${ }^{40}$. Its advantages are smaller subjectivity in the assessment of the symptoms and better correlation with the functional capacity. It lacks, however, data about mortality. 


\section{Cardiothoracic ratio}

This is an easily obtainable parameter, and its increase has been associated with worse prognosis. In the Veterans' studies, the cardiothoracic ratio was an independent predictor of mortality, surpassed only by EF and peak exercise oxygen consumption ${ }^{36}$. Nicklas et al ${ }^{14}$ showed that a cardiothoracic ratio higher than 0.52 was related to higher mortality. In another study, where only noninvasive prognostic factors were evaluated, the cardiothoracic ratio was between the three strongest parameters independently associated with mortality $^{41}$.

The cardiothoracic ratio has limitations. As the cardiac silhouette in the anteroposterior projection is mainly formed by the right chambers, the cardiothoracic ratio changes only in the greatly dilated hearts, being, therefore, a specific index but one with little sensitivity ${ }^{5}$.

\section{Ejection fraction}

The EF of the LV can be obtained, in a noninvasive way, using echocardiography or radionuclide ventriculography. In patients with systolic dysfunction of the LV, the $\mathrm{EF}$ is among the strongest predictors of mortality ${ }^{10,15,36,42}$. In the SOLVD study ${ }^{10}$, patients with EF of $23 \%$ to $35 \%$, with a mean follow-up of 41.4 months, had a mortality rate of $28 \%$; for those with EF of $23 \%$ to $29 \%$, this rate was $39 \%$; and for those with EF of $6 \%$ to $22 \%$, the mortality rate was $50 \%$. Other studies showed similar results. In the study of Cohn et $\mathrm{al}^{36}$, patients with EF smaller than $25 \%$ had a worse prognosis than those whose EF was greater than $35 \%$. Serial studies of EF are also useful in the evaluation of prognosis. In a study ${ }^{43}$, a reduction of the EF greater than $5 \%$ in one year was associated with a mortality almost two times higher.

The EF of the right ventricle (RV) has also shown to be a predictor of mortality. DiSalvo et $\mathrm{al}^{44}$, through radionuclide ventriculography of the RV, showed that a EF higher than $35 \%$ was more strongly correlated with survival than the isolated oxygen consumption $\left(\mathrm{VO}_{2}\right)$. Another advantage of this parameter is that it correlates very well with the exercise capacity measured using $\mathrm{VO}_{2}$, the opposite of what happens with the measurements of the LV function ${ }^{5}$.

\section{Exercise capacity}

Decreased tolerance to exercise is a frequent symptom in CHF. This way, the degree of the patient's tolerance to effort provides significant information and can be measured in an objective way. A frequently used index to assess the exercise capacity is $\mathrm{VO}_{2}$, which provides indirect information about the cardiovascular and pulmonary reserves and has been useful in the prognostic evaluation of the patients with $\mathrm{CHF}^{28,45,46}$. Maximum oxygen consumption would be the ideal index, but it is often impossible to be obtained because the patient usually interrupts the effort before that point, due to muscular fatigue and exhaustion. Therefore, peak exercise $\mathrm{VO}_{2}$ is more usually cited ${ }^{47}$.
Szlachcic et al ${ }^{45}$ were the first to demonstrate the association of $\mathrm{VO}_{2}$ with prognosis. In that study, the survival of individuals with $\mathrm{VO}_{2}$ higher than $10 \mathrm{~mL} / \mathrm{kg} / \mathrm{min}$ was $80 \%$ compared to only $20 \%$ for those with $\mathrm{VO}_{2}$ smaller than that value. Mancini et $\mathrm{al}^{46}$ showed similar results. To a similar degree of EF reduction, patients with a peak exercise $\mathrm{VO}_{2}$ smaller than $14 \mathrm{~mL} / \mathrm{kg} / \mathrm{min}$ had a higher mortality in one year $(30 \%$ to $50 \%)$ than those with exercise capacity preserved, whose mortality was smaller than $10 \%$. Maximum $\mathrm{VO}_{2}$ is also useful in the indication for heart transplantation. Values smaller than $14 \mathrm{ml} / \mathrm{kg} / \mathrm{min}$ indicate possible transplantation and when values are smaller than $10 \mathrm{~mL} /$ $\mathrm{kg} / \mathrm{min}$ the transplantation indication is definitive ${ }^{48,49}$.

In Chagas' cardiomyopathy, $\mathrm{VO}_{2}$ is a significant prognostic factor ${ }^{31,50,51}$. In the study by Mady et $\mathrm{al}^{31}$, maximum $\mathrm{VO}_{2}$, along with $\mathrm{EF}$, was an independent predictor of mortality during an average 30-month follow-up.

On the other hand, $\mathrm{VO}_{2}$ was not a good predictor of mortality in the studies by Wilson et al ${ }^{52}$ and Franciosa et al $^{53}$. Another important fact is that there may not be any correlation between $\mathrm{VO}_{2}$ and $\mathrm{EF}^{36,37}$, showing the independent prognostic value of these two variables.

Another test used to assess exercise capacity is the six-minute walking test ${ }^{54,55,56}$, which correlates well with the patient's symptoms during daily activities ${ }^{5}$. In the studies by Sueta et al ${ }^{57}$ and Bittner et al ${ }^{58}$, there was a strong correlation between the distance walked and survival. Bittner et al ${ }^{58}$ showed that when the distance walked was smaller than $305 \mathrm{~m}$, the annual mortality was $11 \%$ compared to only $4 \%$, when the distance walked was higher than $443 \mathrm{~m}$. In this latter study, the six-minute walking test was also a predictor of future hospitalizations.

\section{Hemodynamic variables}

Several authors ${ }^{59-62}$ found a worse prognosis for patients with hemodynamic variables severely altered. Creager et al ${ }^{60}$ found a worse prognosis in patients with reduced cardiac output. Franciosa ${ }^{62}$ found a higher mortality in patients with LV filling pressures higher than $27 \mathrm{mmHg}$, systemic vascular resistance higher than 23 Wood units, and cardiac index smaller than $2.25 \mathrm{~L} / \mathrm{min} / \mathrm{m}^{2}$. Some authors, however, found no significant correlation between LV filling pressures, cardiac output and mortality, even though these variables were slightly altered in those who did not survive ${ }^{52,63}$.

Right atrium (RA) pressure has also been correlated with survival. In the studies by Creager et al ${ }^{60}$, Unverferth et al ${ }^{61}$, and Lee and Packer ${ }^{64}$, patients with a smaller RA pressure had a better prognosis than those with high pressures in this chamber. In another study ${ }^{57}$, the mean pulmonary pressure was the only hemodynamic variable independently related with a worse prognosis in patients with CHF treated on an outpatient basis.

It is interesting to note that even though the hemodynamic variables, when significantly altered, indicate a 
worse prognosis; no correlation between these variables and the symptoms or the exercise capacity was found $52,61,65$. Treatment with drugs that increase the cardiac index and reduce the filling pressures also did not increase survival ${ }^{66}$. It is important to note that the hemodynamic parameters are useful mainly when a population with varied severity of symptoms is assessed ${ }^{62}$.

\section{Neurohormonal system}

In patients in advanced stages of CHF (FC III and IV and low EF), the hemodynamic and functional factors are no longer predictors of the disease course, and the factors related to the neurohormonal system are fundamental for determining prognosis ${ }^{27,52,63,67}$. Several systems are activated in CHF in order to compensate for the circu-latory disorder caused by reduction of the cardiac output. The sympathetic nervous and the renin-angiotensin-aldosterone (RAAS) systems cause vasoconstriction and water retention, in an attempt to compensate the low cardiac output and the poor tissular perfusion ${ }^{68,69}$. Excessive and prolonged activation of these systems, however, ends up being pernicious ${ }^{67}$. Vasodilating systems are also activated aiming to reduce the noxious effects of the vasoconstrictors ${ }^{69}$. The prognostic value of the main systems involved in the pathophysiology of CHF will be discussed below.

Sympathetic nervous system - The plasmatic level of norepinephrine reflects the activity of the sympathetic nervous system ${ }^{67}$ and is substantially increased in patients with $\mathrm{CHF}$, proportionally to the clinical severity of the disease ${ }^{67,70-72}$. This elevation precedes and predicts the development of CHF, even in patients with asymptomatic ventricular dysfunction ${ }^{27,67,70}$.

Countless studies show the prognostic value of the plasmatic concentration of norepinephrine ${ }^{27,36,60,67,70,72}$. In the study by Cohn et al ${ }^{27}$, values between 400 and $800 \mathrm{ng} / \mathrm{mL}$ were related to high mortality. Patients with levels higher than $800 \mathrm{ng} / \mathrm{mL}$ had a 24 -month survival lower than $20 \%$. In that study, the dosage of norepinephrine was also useful to determine the mode of death. Individuals who died because of the progression of the CHF had average levels of $1,014 \mathrm{ng} / \mathrm{mL}$ compared to $619 \mathrm{ng} / \mathrm{mL}$ in those who died suddenly. This difference is statistically significant. It is important to emphasize that the prognostic significance of norepinephrine depends on the population being studied and it is higher in patients in advanced stages of the disease ${ }^{67,70}$.

Sympathetic hyperactivity is not only a prognostic determinant but it also seems to contribute directly to clinical and hemodynamic worsening of CHF. This conclusion can be drawn from the results of multicenter studies that showed an improvement of the hemodynamic parameters and reduction of mortality due to the use of drugs that block beta-adrenergic receptors ${ }^{73-78}$. Opposite results were obtained with agonists of these receptors ${ }^{79-81}$.
Renin-angiotensin-aldosterone system - The plasmatic activity of renin reflects the degree of activation of the RAAS ${ }^{63,82}$ and its levels are increased in CHF, in the same proportion of disease severity ${ }^{63,67,83}$. Activation of the RAAS contributes directly to the deterioration of $\mathrm{CHF}^{84}$, as shown by clinical trials with ACEI ${ }^{10,34,85,86}$, whose results show improvement of clinical findings and increase of survival with these drugs. As the sympathetic activity, the RAAS activation is more important as a prognostic factor in the more severe patients, in whom the hemodynamic variables are no longer able to predict the prognosis ${ }^{67}$.

The renin activity has a linear inverse relation with the plasmatic concentration of sodium ${ }^{63,67,87-89}$, so that the presence of hyponatremia identifies a group of individuals with great activation of the RAAS ${ }^{67}$. This relation is partially due to the fact that RAAS has a great importance in the pathogenesis of the hyponatremic $\mathrm{CHF}^{90}$. In fact, patients with hyponatremia have clinical characteristics similar to those with high levels of renin, i. e., they tend to be clinically decompensated, with high levels of circulating hormones and they frequently have prerenal uremia ${ }^{67,83}$. Tissular hypoperfusion that exists in $\mathrm{CHF}$ and the action of angiotensin II stimulate, in a nonosmotic way, the release of vasopressin ${ }^{91}$, which through its antidiuretic action may contribute to hyponatremia ${ }^{67,91,92}$.

In 1984, Cohn et al ${ }^{27}$ were the first to show the prognostic importance of hyponatremia and the plasmatic renin. In their study on 106 patients with $\mathrm{CHF}$, these two variables were associated with mortality through univariate analysis. In multivariate analysis, however, they lost their statistical value, being surpassed by plasmatic catecholamines. Two years later, Lee and Packer ${ }^{63}$ showed in a definitive way the prognostic value of sodium and plasmatic renin. Patients with sodium higher than $137 \mathrm{mEq} / \mathrm{L}$ had a greater survival than those with mild hyponatremia (133 to $137 \mathrm{mEq} / \mathrm{L}$ ) or moderate to severe hyponatremia $(<133 \mathrm{mEq} / \mathrm{L})^{63,67}$. Those with sodium $<130 \mathrm{mEq} / \mathrm{L}$ had an one-year survival rate lower than $20 \%$ compared to those with serum sodium higher than that value, whose survival rate was almost $50 \%$.

In a recent study ${ }^{93}$ involving patients with decompensated CHF admitted to the emer-gency department, we observed that the presence of hyponatremia was the only factor independently related to hospital mortality and survival at 16-month follow-up, among routine clinical, laboratorial and echocardiographic variables. Global mortality was $52 \%$ for patients with serum sodium $<135 \mathrm{mEq} / \mathrm{L} \mathrm{com}-$ pared to $16.6 \%$ for those with serum sodium $>135 \mathrm{mEq} / \mathrm{L}$.

The SOLVD study ${ }^{14}$ confirmed the prognostic value of the RAAS in CHF. The plasmatic activity of renin, as well as the plasmatic norepinephrine and the atrial natriuretic factor (ANF) were strong predictors of mortality in one year.

In the CONSENSUS I study ${ }^{94}$, increased levels of angiotensin II and aldosterone, in addition to norepinephrine and ANF, had a significant correlation with mortality. Angiotensin II had a stronger correlation than norepinephrine, the opposite of what had been found in 
previous studies. This fact can result from the type of population studied in CONSENSUS, where only patients in FCIV were included ${ }^{5}$.

Aldosterone in animal models plays an important role in the proliferation of fibroblasts and in myocardial fibrosis ${ }^{5}$. In the SOLVD study ${ }^{95}$, the ACEIs caused reduction of the myocardial mass measured by echocardiography and, in the CONSENSUS study ${ }^{94}$, they reduced the aldosterone levels by almost $60 \%$. These findings suggest that aldosterone has a deleterious effect on the failing myocardium. The RALES study ${ }^{96}$ that assessed the effect of spironolactone, an inhibitor of aldosterone, in the mortality of patients with $\mathrm{CHF}$ was recently interrupted for evidencing the benefits of the drug (unpublished data).

Vasopressin - Arginine vasopressin is released in response to a reduction in intracellular volume (osmotic stimulus) or in response to a reduction in extracellular volume or in blood pressure (nonosmotic stimulus). It acts increasing the water reabsorption in the kidneys and causing systemic vasoconstriction ${ }^{68}$.

Vasopressin plasmatic concentration is increased in patients with severe $\mathrm{CHF}^{67,91,92,97}$. Its exact role in the pathophysiology of CHF, however, is not clear. It is known that, in hyponatremic CHF, vasopressin is frequently increased, along with renin activity, and it has been implicated in the pathogenesis of the disturbance of water metabolism found in this condition. Goldsmith et al ${ }^{97}$, however, did not find any correlation between vasopressin and serum sodium or osmolarity in patients with CHF, suggesting that hyponatremia is not a simple outcome of the release of vasopressin in this syndrome.

The value of vasopressin as an independent prognostic factor is not well defined, and there are no data suggesting that it has a direct deleterious effect on survival ${ }^{67}$. In the SOLVD study ${ }^{14}$, the serum level of vasopressin was not a predictor of mortality.

Atrial natriuretic factor - In 1985, Lang et al ${ }^{98}$ demonstrated the presence of this factor in humans, for the first time. The main stimulus for its release is atrial distension or stretch and not the increase of pressure ${ }^{99}$. It has a diuretic, natriuretic and vasodilating action, the opposite of the deleterious effects of the vasoconstrictive hormones ${ }^{67,69}$.

Plasmatic levels of ANF are increased in $\mathrm{CHF}^{67,100-102}$. In the CONSENSUS ${ }^{103}$ and SAVE ${ }^{104}$ studies, these levels correlated with the symptoms, cardiac index, and LV filling pressure, but not with EF. Values superior to $125 \mathrm{ng} / \mathrm{mL}$ were related to a greater mortality ${ }^{104}$.

Brain natriuretic factor - This factor was discovered in $1988^{105}$. It has a great chemical similarity to the $\mathrm{ANF}^{106}$. Patients with CHF have extremely elevated plasmatic levels of this peptide, and its release by the patient's ventricles is also quite increased ${ }^{107,108}$. As the ANF, the brain natriuretic factor seems to play a significant role in the pathophysiology of the CHF, acting as an endogenous vaso- dilator and diuretic. The clinical improvement observed when it is administered to patients with CHF confirms this hypothesis ${ }^{109}$. Its importance as a prognostic factor was recently demonstrated. McDonagh et al ${ }^{110}$, in a populationbased study carried out in Glasgow, Scotland, demonstrated that values of the brain natriuretic factor superior to $17.9 \mathrm{pg} / \mathrm{mL}$ were independently related to total and cardiovascular mortality. In addition to the prognostic value, it is worth emphasizing the great accuracy of this method in the diagnosis of the ventricular systolic dysfunction, where it is increased even in the asymptomatic phase, and can be used as a screening test for early identification of these individuals (Dargie, personal communication).

Prostaglandins - Prostaglandins are not true hormones, but autacoids, i. e., they are locally synthesized and activated ${ }^{69}$. Metabolites of prostaglandin, such as $\mathrm{PGI}_{2}$ and $\mathrm{PGE}_{2}$, however, are circulating substances and are increased in $\mathrm{CHF}^{67,69,88,111,112}$. This increase is partially due to a direct response to systemic hypoperfusion and also to stimulation of activated vasoconstrictive hormones, especially angiotensin $\mathrm{II}^{67}$. As observed with the vasoconstrictive hormones, the activity of prostaglandins increase with the aggravation of the disease ${ }^{69}$.

Patients with advanced CHF are strongly dependent on prostaglandin to maintain an adequate renal function, with an appropriate excretion of sodium ${ }^{69}$. In hyponatremic patients, worsening of CHF was observed after utilization of drugs that inhibit the synthesis of prostaglandin, such as indomethacin ${ }^{88}$. There was a decrease in the cardiac index and an increase in systemic vascular resistance and pulmonary capillary pressure.

In patients with chronic $\mathrm{CHF}^{67}$, the metabolites of prostaglandin are accurate - although not independent prognostic markers because of their relation to hyponatremia.

Endothelins - A potent vasoconstrictor produced by the cells of the vascular endothelium, called endothelin, was described by Yanagisawa et al $^{113}$, in 1988. Today, at least four different isoforms (ET-1,ET-2,ET-3, and an intestinal vasoactive form) are known. Once released, they have a great variety of effects on the cardiovascular, renal, pulmonary, and neuroendocrine systems, acting in two distinct receptors $\left(\mathrm{ET}_{\mathrm{A}} \text { and } \mathrm{ET}_{\mathrm{B}}\right)^{69}$.

Endothelins levels are tripled in patients with $\mathrm{CHF}^{114-116}$ and correlate with the $\mathrm{FC}^{114,116}$ and the degree of pulmonary hypertension ${ }^{117}$. A precursor named big endothelin-1 was an important predictor of short-term mortality in patients with advanced CHF, surpassing hemodynamic variables and ANF ${ }^{118}$. Blockers of endothelin receptors and inhibitors of the endothelin-converting enzyme have been developed and should help to clarify the role endothelins play in the genesis and prognosis of $\mathrm{CHF}^{69,119}$.

Cytokines - Some peptide mediators, such as growth factors and inflammatory cytokines, have important effects on the myocardium and blood vessels and seem to be 
involved in the genesis of $\mathrm{CHF}^{120}$. Growth factors may cause hypertrophy associated with the expression of fetal genes ${ }^{120}$. Inflammatory cytokines, such as the alpha tumor necrosis factor, may cause immediate myocardial damage in vitro ${ }^{120}$ and are increased in $\mathrm{CHF}^{121}$. Another inflammatory cytokine, beta interleukin-1, causes myocardial hypertrophy in vitro ${ }^{122}$.

Cytokines may be involved, in the long run, in myocardial remodeling and alterations of the vascular tissue ${ }^{120}$. Their role in the pathophysiology and prognosis of $\mathrm{CHF}$, however, is yet to be defined.

\section{Thyroid function}

Alterations in the metabolism of the thyroid hormones, such as hyper- or hypothyroidism, are known as cause or precipitating factors of $\mathrm{CHF}^{123}$. Lately, these hormones have been observed to also have prognostic value. In CHF, Hamilton et al ${ }^{124}$ evaluated the situation called "state of euthyroid disease" characterized by low triiodothyronine $\left(\mathrm{T}_{3}\right)$ or $\mathrm{T}_{3}$ index, increased reverse $\mathrm{T}_{3}$, normal thyrotropin (TSH), and variable thyroxine $\left(\mathrm{T}_{4}\right)$. They studied 84 patients admitted to the coronary unit with severe $\mathrm{CHF}$ and reported that the decrease of the free $\mathrm{T}_{3}$ index/reverse $\mathrm{T}_{3}$ ratio was an important predictor of mortality in the short-term, surpassing variables such as EF, serum sodium and hemodynamic variables.

\section{Cardiac arrhythmias}

Patients with severe CHF have high incidence of ventricular arrhythmias when evaluated through dynamic electrocardiography $20,24,125,126$. Multifocal and paired ventricular extrasystoles are common and more complex arrhythmias, such as nonsustained ventricular tachycardias (NSVT), are found in $50 \%$ of the individuals ${ }^{125}$.

It is known that the frequency and complexity of the ventricular ectopic beats are not directly responsible for higher mortality, but only reflect the hemodynamic and functional severity of the disease, being related to the degree of impairment of ventricular function ${ }^{61,127}$. In fact, the utilization of antiarrhythmic drugs of the group I-C in asymptomatic patients with frequent ventricular arrhy-thmias, previous myocardial infarction and low EF caused increase in mortality, despite suppressing the arrhythmias ${ }^{128}$.

The presence of these arrhythmias, however, provide additional prognostic information, even in the thrombolytic era. Data from the GISSI study ${ }^{129}$ show that, in postinfarction patients with $\mathrm{EF}<35 \%$, the presence of 10 or more ectopic beats per hour or complex ventricular ectopia is associated with an increase of 2.1 to 2.4 times of the risk of sudden death.

The presence of NSVT increases the risk of death by three times ${ }^{130}$ and has been described as an independent predictor of sudden death ${ }^{131}$. The annual mortality for patients with previous myocardial infarction, $\mathrm{EF}<30 \%$ and presence of NSVT reaches $40 \%$ compared to $20 \%$ for those without NSVT ${ }^{126,130}$.
Sustained monomorphic ventricular tachycardia occurs in approximately $9 \%$ of the patients with severe $\mathrm{CHF}$ referred for cardiac transplantation ${ }^{132}$. Its presence identifies a group with high probability of recurrence of arrhythmia and sudden death ${ }^{133,134}$. Ventricular fibrillation usually occurs in the presence of acute myocardial ischemia or severe ventricular dysfunction. As sustained ventricular tachycardia, ventricular fibrillation has a high index of recurrence, therefore justifying aggressive therapeutics ${ }^{134}$.

Atrial arrhythmias have also been associated with worse prognosis. The presence of atrial fibrillation has been related to a higher incidence of embolic phenomena and sudden death, in the majority of the studies of $\mathrm{CHF}^{135}$. An exception to this finding was the Veterans study ${ }^{136}$, which, however, did not include patients in FC IV.

Left bundle branch blockade (LBBB) was described as an important prognostic factor in the study of Unverferth et al $^{61}$. In a prospective study, Franciosa ${ }^{62}$ observed a strong correlation between arrhythmic events and the presence of LBBB in the basal electrocardiogram (ECG). According to Hermann and Greenberg ${ }^{5}$, however, the usefulness of these findings is limited by the high prevalence of electrocardiographic abnormalities in $\mathrm{CHF}$.

Invasive electrophysiological study - This exam has been used in the attempt to identify patients at risk for sudden death. Its value in patients with cardiomyopathy is not clear yet. In a metanalysis performed by Kowey et al ${ }^{137}$ of 12 studies including 926 patients with NSVT, one out of three patients had sustained arrhythmia induced in the invasive electrophysiological study (sustained monomorphic ventricular tachycardia). During follow-up, $7 \%$ of the noninducible patients had events (sustained ventricular tachycardia, ventricular fibrillation and sudden death) compared to $18 \%$ of the inducible ones. The use of antiarrhythmic drugs in inducible patients, however, impairs the interpretation of these data because of the possibility of pro-arrhythmia.

Signal-averaged ECG - In a patient with previous infarction, the presence of late potentials is associated with induction of tachycardia in the electrophysiological study and with the increased incidence of arrhythmic events (sudden death and sustained ventricular tachycardia) ${ }^{138}$. The limitation of this method is that despite presenting elevated negative predictive value ${ }^{126}$, its positive predictive value is low ${ }^{139}$. Its accuracy can be enhanced when its results are combined with data of ventricular function, mainly the left ventricle ejection fraction (LVEF) ${ }^{140,141}$.

In patients with nonischemic dilated cardiomyopathy and history of sustained ventricular tachycardia, the prevalence of late potentials is high, reaching $80 \%{ }^{142}$. In patients with NSVT, the presence of late potentials varies and does not seem to predict the occurrence of sudden death ${ }^{143}$. Mancini et al ${ }^{144}$ evaluated the prognostic value of the signal averaged ECG (SAE) in patients with nonis- 
chemic dilated cardiomyopathy. Of 66 patients with normal exam, none had arrhythmic events during the follow-up. On the other hand, from the 20 patients with abnormal exams, four had ventricular tachycardia and five died suddenly. In multivariate analysis, SAE was an independent predictor of prognosis. It is interesting to notice that among the patients with abnormal exams, nine had a previous history of ventricular tachycardia or sudden death compared to only one among those with a normal exam.

Other authors obtained different results. Yi et al ${ }^{145}$, studying patients with idiopathic dilated cardiomyopathy, showed that abnormal SAE identified patients who evolved with progression of the CHF, but did not identify the patients who died suddenly.

Dispersion of the Q-T interval- This method has been pointed out by some authors ${ }^{146,147}$ as an important prognostic variable in CHF. Barr et al ${ }^{146}$ showed that individuals who died suddenly had a higher dispersion of the Q-T interval (mean $98.6 \mathrm{~ms}$ ) than those who survived (mean $53.1 \mathrm{~ms}$ ) or those who died due to CHF progression (mean $66.7 \mathrm{~ms}$ ). Pinsky et al ${ }^{147}$ observed, in patients awaiting heart transplantation, that dispersion of the Q-T interval higher than $140 \mathrm{~ms}$ was an important predictor of death, both sudden and due to CHF progression.

\section{Autonomic dysfunction}

The autonomic balance upon the heart has been consistently evaluated through the heart rate variability $(\mathrm{HRV})$, using measures in the time and frequency domain (spectral analysis). In patients with CHF, the HRV is greatly reduced, reflecting sympathetic hyperactivity and reduction of vagal activity, correlating with the severity of the disease ${ }^{148-150}$. Several authors found correlation between HRV, LVEF ${ }^{148,150}$, and also the plasmatic level of noradrenaline ${ }^{149,151}$. Kienzle et al ${ }^{151}$ did not find correlation between HRV and EF or FC. They observed, however, a strong negative correlation with indicators of sympathetic excitation, sympathetic neuromuscular activity, and plasmatic level of noradrenaline.

In the last five years, HRV has been shown to of important prognostic value in $\mathrm{CHF}^{149,152-154}$. Despite the small number of patients in the series, the largest consisting of 102 patients ${ }^{153}$, the results have been consistent. Binder et al ${ }^{152}$, studying patients awaiting heart transplantation, observed that those with SDANN (an index of HRV in the time domain) of $55 \mathrm{~ms}$ had a 20 -time increase in the risk of death. The authors suggest that HRV is superior to other prognostic factors, such as EF, pulmonary capillary pressure, cardiac index, and serum sodium. Mortara et al ${ }^{149}$, studying patients before and just after heart transplantation, found similar results.

Recently, Ponikowski et al ${ }^{153}$ showed that HRV is an independent prognostic factor in patients with CHF secondary to ischemic or idiopathic dilated cardiomyopathy. Patients with SDNN (another index of HRV in the time domain) inferior to $100 \mathrm{~ms}$ had a 3.8-time higher risk of death than those whose indices are higher than that value. In another recent study, Fauchier et al ${ }^{154}$ observed that, in patients with idiopathic dilated cardiomyopathy, the analysis of the HRV can identify individuals at greater risk of death or evolution to heart transplantation. In this study, the HRV was reduced, even in patients without manifest heart failure. This reduction, however, was much more pronounced when there was deterioration of the hemodynamic state.

We emphasize that in the majority of these studies, the HRV was correlated with the degree of ventricular dysfunction and the presence of cardiac arrhythmias ${ }^{148-150,154}$. In fact, in the study by Fei et al ${ }^{150}$, the measures of HRV were not predictors of sudden death in patients with ischemic or idiopathic dilated cardiomyopathy, in a oneyear follow-up.

\section{Final comments}

CHF is a potentially lethal syndrome, whose prevalence is increasing throughout the world. The stratification of death risk is essential for the early identification of individuals with a higher chance of adverse events, so that a more aggressive therapy or even extreme interventions, such as the use of implantable defibrillators, heart transplantation or drugs under investigation, can be utilized.

The etiology of CHF, the demographic profile of the patient, and the presence of comorbidities influence the prognosis. An individualized and careful investigation is necessary to detect abnormalities that can be corrected. Patients who do not respond to the conventional therapy or whose etiology is not clear should be referred to specialized centers or to experts in the area of heart failure and cardiomyopathies. 


\section{References}

1. McKee PA, Castelli WP, McNamara PM, Kannel WB - The natural history of congestive heart failure: the Framingham study. N Engl J Med 1971; 285: 1441-6.

2. Ho KKL, Pinsky JL, Kannel WB, Levy D - The epidemiology of heart failure: The Framingham study. J Am Coll Cardiol 1993; 22(suppl A): 6A-13A.

3. Brasil. Ministério da Saúde. Secretaria Nacional de Assistência à Saúde. Instituto Nacional de Câncer - Coordenação de Programas de Controle do Câncer/ Pró-Onco. Estimativa da incidência e mortalidade por câncer no Brasil para 1997. Rio de Janeiro, 1997.

4. Abraham WT, Bristow MR - Specialized centers for heart failure management Circulation 1997; 96: 2755-7.

5. Hermann DD, Greenberg BH - Prognostic factors. In: Poole-Wilson PA, Colucci WS, Massie BM, Chattenjee K, Coats AJS, eds - Heart Failure. New York: Churchill Livingstone, 1997: 439-54.

6. Schocken DD, Arrieta MI, Leverton PE, Ross EA - Prevalence and mortality rate of congestive heart failure in the United States. J Am Coll Cardiol 1992; 20: 301-6.

7. Barreto ACP, Arteaga E, Mady C, Ianni BM, Bellotti G, Pileggi F- Sexo masculino: fator prognóstico na doença de Chagas. Arq Bras Cardiol 1993; 60: 225-7.

8. Mady C - Insuficiência cardíaca: história natural e prognóstico. Arq Bras Cardiol 1994; 63: 515-7.

9. Bourassa MG, Gurne O, Bangdiwala SI, et al, for the Studies of Left Ventricula Dysfunction (SOLVD) Investigators - Natural hystory and patterns of current practice in heart failure. J Am Coll Cardiol 1993; 22(suppl A): 14A-19A.

10. The SOLVD investigators - Effect of enalapril on survival in patients with reduced left ventricular ejection fraction and congestive heart failure. $\mathrm{N}$ Engl J Med 1991; 325: 294-302.

11. Adams KF Jr, Dunlap SH, Sueta CA, et al - Relation between gender, etiology and survival in patients with symptomatic heart failure. J Am Coll Cardiol 1996; 28 : 1781-8.

12. DeMaria R, Gavazzi A, Recalcati F, et al - Comparison of clinical findings in idiopathic dilated cardiomyopathy in women versus men. Am J Cardiol 1993; 72: $580-5$

13. Lindenfeld J, Krause-Steinrauf H, Salerno J - Where are all the women with heart failure? J Am Coll Cardiol 1997; 30: 1417-9.

14. Nicklas JM, Benedict C, Johnstone DE, et al - Relationship between neurohumora profile and one year mortality in patients with congestive heart failure and/or left ventricular dysfunction. Circulation 1991; 84(suppl II): II-468.

15. Hughes CV, Wong M, Johnson GJ, Cohn JN-Influence of age on mechanisms and prognosis of heart failure. Circulation 1993; 87(suppl VI): 111-6.

16. Fein FS, Sonnenblick EH - Diabetic cardiomyopathy. Cardiovasc Drug The 1994; 8: 65-9.

17. Kannel WB, Hjortland M, Castelli WP - Role of diabetes in congestive heart failure. The Framingham Study. Am J Cardiol 1974; 34: 29-34.

18. Golper TA - Dialysis and hemofiltration for congestive heart failure. In Hosenpud JD, Greenberg BH, eds - Congestive Heart Failure. Pathophysiology, Diagnosis and Comprehensive Approach to Management. New York: SpringerVerlag, 1994: 568

19. Canaud B, Cristol JP, Klouche K, et al - Slow continuous ultrafiltration: a mean of unmasking myocardial functional reserve in end-stage cardiac disease. Contrib Nephrol 1991; 93: 79-83

20. Domanski MJ, Garg R, Yusuf S - Prognosis in congestive heart failure. In Hosenpud JD, Greenberg BH, eds - Congestive Heart Failure: Pathophysiology, Diagnosis, and Comprehensive Approach to Management. New York: SpringerVerlag, 1994: 622-7.

21. Franciosa JA, Wilen M, Ziesche S, Cohn JN - Survival in men with severe chronic left ventricular failure due to either coronary heart disease or idiopathic dilated cardiomyopathy. Am J Cardiol 1983; 51: 831-6.

22. Itoh A, Saito M, Haze K, et al - Prognosis of patients with congestive heart failure: its determinants in various heart diseases in Japan. Int Med 1993; 31: 304-9.

23. A ndersson B, Waagstein F- Spectrum and outcome of congestive heart failure in a hospitalized population. Am Heart J 1993; 126: 632-40.

24. Dargie HJ, Cleland JGF, Leckie BJ, Inglis CG, East BW, Ford I - Relation of arrhythmias and electrolyte abnormalities to survival in patients with severe chronic heart failure. Circulation 1987; 75(suppl IV): IV-98.

25. Bart BA, Shaw LK, McCants CB Jr, et al - Clinical determinants of mortality in patients with angiographically diagnosed ischemic or nonischemic cardiomyopathy. J Am Coll Cardiol 1997; 30:1002-8

26. Goldman S, Johnson G, Cohn JN, Cintron G, Smith R, Francis G - Mechanism of death in heart failure: the vasodilator-heart failure trials. Circulation 1993 87(suppl VI): VI-24.

27. Cohn JN, Levine TB, Olivari MT, et al - Plasma norepinephrine as a guide to prognosis in patients with chronic congestive heart failure. N Engl J Med 1984 311: 819-23.

28. Parameshwar J, Keegan J, Sparrow J, Sutton GC, Poole-Wilson PA - Predictors of prognosis in severe chronic heart failure. Am Heart J 1992; 123: 421-6.

29. Bingisser R, Candinas R, Schneider J, Hess OM - Risk factors for systolic dysfunction and ventricular dilatation in hypertrophic cardiomyopathy. Int $\mathrm{J}$ Cardiol 1994; 44: 225-9.

30. Barreto ACP, da Luz PL, de Oliveira SA, et al - Determinants of survival in endomyocardial fibrosis. Circulation 1989; 80(suppl I): 177.

31. Mady C, Cardisso RH, Barreto AC, et al - Survival and predictors of survival in patients with congestive heart failure due to Chagas' cardiomyopathy Circulation 1994; 90: 3098

32. Hosenpud JD - Restrictive cardiomyopathy. In: Zipes DP, Rowlands DJ, eds Progress in Cardiology. Philadelphia: Lea \& Febiger, 1989: 91.

33. Barreto ACP, Precoma D, Serro-Azul JB, et al - Amiloidose cardíaca: uma doença de muitas faces e diferentes prognósticos. Arq Bras Cardiol 1997; 69: 89-93.

34. CONSENSUS Trial Study Group - Effects of enalapril on mortality in severe congestive heart failure. Results of the Cooperative North Scandinavian Enalapril Survival Study (CONSENSUS). N Engl J Med 1987; 316: 1429-35.

35. Cohn JN, Johnson G, Ziesche S, et al - Effect of vasodilator therapy on mortality in chronic congestive heart failure: results of a Veterans Administration Cooperative Study (V-HeFT I). N Engl J Med 1986; 314: 1547-52.

36. Cohn JN, Johnson GR, Shabetai R, et al - Ejection fraction, peak exercise oxygen consumption, cardiothoracic ratio, ventricular arrhythmias, and plasma norepinephrine as determinants of prognosis in heart failure. Circulation 1993; 87(suppl VI): 5

37. Smith RF, Johnson G, Ziesche S, et al - Functional capacity in heart failure: comparison of methods for assessment and their relations to other indexes of heart failure. Circulation 1993; 87(suppl VI): 88

38. Cohn JN, Johnson G - Heart failure with normal ejection fraction. The V-HeFT study. Circulation 1990; 81(suppl III): 48.

39. Brogan WC, Hillis LD, Flores ED, Lange RA - The natural history of isolated left ventricular diastolic dysfunction. Am J Med 1992; 92: 627-30.

40. Goldman L, Hashimoto B, Cook EF, Loscalzo A - Comparative reproducibility and validity of systems for assessing cardiovascular functional class: advantages of a new specific activity scale. Circulation 1981; 64: 1227-31.

41. Spinar J, Vitovec J, Spac J, Blaha M, Spiranova L, Toman J - Non-invasive prognostic factors in chronic heart failure: one-year survival of 300 patients with a diagnosis of chronic heart failure due to ischemic heart disease or dilated cardiomyopathy. Int J Cardiol 1996; 56: 283-8.

42. Gradman A, Deedwania P, Cody R, et al - Predictors of total mortality and sudden death in mild to moderate heart failure. J Am Coll Cardiol 1989; 14: 564-70.

43. Cintron G, Johnson G, Francis G, et al - Prognostic significance of serial changes in left ventricular ejection fraction in patients with congestive heart failure. Circulation 1993; 87 (suppl VI): 17.

44. DiSalvo TG, Mathier M, Semigram MJ, Dec GW - Preserved right ventricular ejection fraction predicts exercise capacity and survival in advanced heart failure. J Am Coll Cardiol 1995; 25: 1143-8.

45. Szlachcic J, Massie B, Kramer B, et al - Correlates and prognostic indicators of exercise capacity in chronic congestive heart failure. Am J Cardiol 1985; 55: 1037-42.

46. Mancini DM, Eisen H, Kussmaul W, et al - Value of peak exercise oxygen consumption for optimal timing of cardiac transplantation in ambulatory patients with heart failure. Circulation 1991; 83: 778-82.

47. McDonagh TA, Dargie HJ - Role of exercise testing. In: Poole-Wilson PA Colucci WS, Massie BM, Chattenjee K, Coats AJS, eds. Heart Failure. New York: Churchill Livingstone, 1997: 455-60.

48. Roul G, Moulichon ME, Bareiss P, et al - Exercise peak $\mathrm{VO}_{2}$ determination in chronic heart failure: is it still of value? Eur Heart J 1994; 15: 495-9.

49. Committee on Evaluation and Management of Heart Failure - Guidelines for the evaluation and management of heart failure. Report of the American College of Cardiology/American Heart Association Task Force on Practice Guidelines. J Am Coll Cardiol 1995: 26: 1376-98

50. Yazbek Jr P, Diament J, Haesbisch H, et al - Ergoespirometria como método de predição do comportamento evolutivo da miocardiopatia isquêmica, chagásica e idiopática. Arq Bras Cardiol 1991; 57: 451-8.

51. Mady C, Cardisso RH, Barreto AC, et al - Survival and predictors of survival in patients with congestive heart failure due to Chagas' cardiomyopathy. Circulation 1994; 90: 3098

52. Wilson JR, Schwartz JS, St. John Sutton M, et al - Prognosis in severe heart failure 
relation to hemodynamic measurements and ventricular ectopic activity. J Am Coll Cardiol 1983; 2: 403

53. Franciosa J, Wilen M, Baker B - Functional capacity and long-term survival in chronic left ventricular failure. Circulation 1983; 68(suppl III): III-149.

54. Guyatt GH, Sullivan MJ, Thompson PI, et al - The 6 minutes walk: a new measure of exercise capacity in patients with heart failure. Can Med Assoc J 1985; 132: 919-23.

55. Lipkin DP, Scriven AJ, Crake T, Poole-Wilson PA - Six minute walking test for assessing exercise capacity in chronic heart failure. Br Med J 1986; 292: 653-7.

56. Oliveira Jr MT, Guimarães GV, Barreto ACP - Teste de seis minutos em insuficiência cardíaca. Arq Bras Cardiol 1996; 67: 373-4.

57. Sueta CA, Gheorghiade M, Adams KF, et al - Safety and efficacy of epoprostenol in patients with severe congestive heart failure. Epoprostenol Multicenter Research Group. Am J Cardiol 1995; 75: 34A.

58. Bittner V, Weiner DH, Yusuf S, et al - Prediction of mortality and morbidity with a six minute walk test in patients with left ventricular dysfunction. JAMA 1993: 270: 1702-6.

59. Massie B, Ports T, Chatterjee K, et al - Long-term vasodilator therapy for heart failure: clinical response and its relationship to hemodynamic measurements. Circulation 1981; 63: 269-74.

60. Creager MA, Faxon DP, Halperin JL - Determinants of clinical response and survival in patients with congestive heart failure treated with captopril. Am Heart J 1982; 104: 1147-51.

61. Unverferth DV, Magorien RD, Moeschberger ML, et al - Factors influencing the one-year mortality of dilated cardiomyopathy. Am J Cardiol 1984; 54: 147-51.

62. Franciosa JA - Why patients with heart failure die: hemodynamic and functional determinants of survival. Circulation 1987; 75(suppl IV): IV-20.

63. Lee WH, Packer M - Prognostic significance of serum sodium concentration and its modifications by converting enzyme inhibition in patients with severe chronic heart failure. Circulation 1986; 73: 257-67.

64. Lee WH, Packer M - Importance of right ventricular function as the primary determinant of clinical response and long-term survival in patients with severe heart failure treated with converting-enzyme inhibitors. J Am Coll Cardiol 1985; 5: 461.

65. Franciosa JA, Park M, Levine TB - Lack of correlation between exercise capacity and indexes of resting left ventricular performance in heart failure. Am J Cardiol 1981; 47: 33-7.

66. Furberg CD, Yusuf S, Thom T - Potential for altering the natural history of congestive heart failure: need for large clinical trials. Am J Cardiol 1985; 55: 45A.

67. Packer M, Lee WH, Kessler PD, Gottlieb SS, Bernstein JL, Kukin ML - Role of neurohormonal mechanisms in determining survival in patients with severe chronic heart failure. Circulation 1987; 75(suppl IV): IV80-IV92.

68. Anand IS - Pathogenesis of salt and water retention in the congestive heart failure syndrome. In: Poole-Wilson PA, Colucci WS, Massie BM, Chattenjee K, Coats AJS, eds - Heart Failure. New York: Churchill Livingstone, 1997: 155-71.

69. Francis GS - Vasoactive hormone systems. In: Poole-Wilson PA, Colucci WS, Massie BM, Chattenjee K, Coats AJS, eds - Heart Failure. New York: Churchill Livingstone, 1997: 215-34.

70. homas J, Marks B - Plasma norepinephrine in congestive heart failure. Am J Cardiol 1978: 41: 233-43.

71. Francis GS, Goldsmith SR, Cohn JN - Relationship of exercise capacity to resting left ventricular performance and basal plasma norepinephrine levels in patients with congestive heart failure. Am J Cardiol 1982; 104: 725-9.

72. Francis GS, Cohn JN, Johnson G, et al - Plasma norepinephrine, plasma renin activity, and congestive heart failure: relations to survival and the effects of therapy in V-HeFT II. Circulation 1993; 87(suppl VI): 40-4.

73. Waagstein F, Bristow MR, Swedberg K, et al - Beneficial effects of metoprolol in idiopathic dilated cardiomyopathy (Metoprolol in Dilated Cardiomyopathy, MDC). Lancet 1993; 342: 1441-6.

74. CIBIS Investigators and Committees - A randomized trial of beta-blockade in heart failure. The Cardiac Insufficiency Bisoprolol Study (CIBIS). Circulation 1994; 90: 1765-73

75. Packer M, Bristow MR, Cohn JN, et al - The effect of carvedilol on morbidity and mortality in patients with chronic heart failure. N Engl J Med 1996; 334: 1349-55.

76. Bristow MR, Gilbert EM, Abraham WT, et al - Carvedilol produces dose-related improvements in left ventricular function and survival in subjects with chronic heart failure. The Multicenter Oral Carvedilol Heart Failure Assessment (MOCHA). Circulation 1996; 94: 2807-16.

77. Colucci WS, Packer M, Bristow MR, et al - Carvedilol inhibits clinical progression in patients with mild symptoms of heart failure. The US Carvedilol Heart Failure Study. Circulation 1996; 94: 2800-6.

78. Lechat $P$, for the CIBIS Investigators and Committees - The Cardiac Insufficiency Bisoprolol Study II (CIBIS-II). The Second Annual Scientific Meeting of the Heart Failure Society of America, Boca Raton - FL - USA, September 15th, 1998.

79. Lambertz H, Meyer J, Erbel R - Long-term hemodynamics effects of prenalterol in patients with severe congestive heart failure. Circulation 1984; 69: 298-302.
80. Roubin GS, Choong CVP, Devenish-Mearis S, et al - Beta-adrenergic stimulation of the failing ventricule: a double-blind, randomized trial of sustained oral therapy with pirbuterol. Circulation 1984; 69: 955: 9.

81. Mettauer B, Rouleau JL, Burgess JH - Detrimental arrhythmogenic and sustained beneficial hemodynamics effects of oral salbutamol in patients with chronic congestive heart failure. Am Heart J 1985; 109: 840-4.

82. Cody RJ, Laragh JH - Use of captopril to estimate renin-angiotensin-aldosterone activity in the pathophysiology of chronic heart failure. Am Heart J 1982; 104: 1184-8.

83. Dzau VJ, Colucci WS, Hollenberg NK, Williams GH - Relation of the reninangiotensin-aldosterone system to clinical state in congestive heart failure. Circulation 1981; 63: 645-9.

84. Kluger VJ, Cody RJ, Laragh JH - The contributions of sympathetic tone and the renin-angiotensin system to severe chronic congestive heart failure: responses to specific inhibitors (prazosin and captopril). Am J Cardiol 1982; 49: 1667-71.

85. Pfeffer MA, Braunwald E, Moye LA, et al - Effect of captopril on mortality and morbidity in patients with left ventricular dysfunction after myocardial infarction. N Engl J Med 1992; 327: 669.

86. The Acute Infarction Ramipril Efficacy (AIRE) Study Investigators - Effect of ramipril on mortality and morbidity of survivors of acute myocardial infarction with clinical evidence of heart failure. Lancet 1993; 342: 821-8.

87. Levine TB, Franciosa JA, Vrobel T, Cohn JN-Hyponatraemia as a marker for high renin heart failure. Br Heart J 1982; 47: 161-5.

88. Dzau VJ, Packer M, Lilly LS, Swartz SL, Hollenberg NK, Williams GH Prostaglandins in severe congestive heart failure: relation to activation of the renin-angiotensin system and hyponatremia. N Engl J Med 1984; 310: 347.

89. Packer M, Medina N, Yushak M - Relation between serum sodium concentration and the hemodynamic and clinical responses to converting enzyme inhibition with captopril in severe heart failure. J Am Coll Cardiol 1984; 3: 1035-9.

90. Packer M, Medina N, Yushak M - Correction of dilutional hyponatremia in severe chronic heart failure by converting-enzyme inhibition. Ann Intern Med 1984; 100: 782-6.

91. Riegger GAJ, Leibau G, Koehsiek K - Antidiuretic hormone in congestive heart failure. Am J Cardiol 1982; 72: 49-53.

92. Szatalowicz VL, Arnold PE, Chaimovitz C, Bichet D, Berl T, Schrier RW Radioimmunoassay of plasma arginine vasopressin in hyponatremic patients with congestive heart failure. N Eng J Med 1981; 305: 263-7.

93. Villacorta H, Rocha N, Cardoso R, et al - Evolução intra-hospitalar e seguimento pós-alta de pacientes idosos atendidos com insuficiência cardíaca congestiva na unidade de emergência. Arq Bras Cardiol 1998; 70: 167-71.

94. Swedberg K, Eneroth P, Kjekshus J, Wilhelmsen L - Hormones regulating cardiovascular function in patients with severe congestive heart failure and their relation to mortality. Circulation 1990; 82: 1730-5.

95. Greenberg BH, Quinones MA, Koilpillai C, et al - Effects of long-term enalapril therapy on cardiac structure and function in patients with left ventricular dysfunction. Results of the SOLVD echocardiography substudy. Circulation 1995; 91: 2573-8.

96. The RALES Investigators - Effectiveness of spironolactone added to an angiotensin-converting enzyme inhibitor and a loop diuretic for severe chronic congestive heart failure. The Randomized Aldactone Evaluation Study (RALES). Am J Cardiol 1996; 78: 902-7.

97. Goldsmith SR, Francis GS, Cowley AW, Levine TB, Cohn JN - Increased plasma arginine vasopressin levels in patients with congestive heart failure. J Am Coll Cardiol 1983; 1:1385-9.

98. Lang RE, Tholken H, Ganten D, et al - Atrial natriuretic factor: a circulating hormone stimulated by volume loading. Nature 1985; 314: 264-9.

99. Edwards BS, Zimmerman RS, Schwab TR, Heublein DM, Burnett JC - Atria stretch, not pressure, is the principal determinant controlling the release of atrial natriuretic factor. Circ Res 1988; 62: 191-5.

100. Bates ER, Shenker EY, Grekin RJ - Plasma atrial natriuretic factor levels are markedly elevated in humans with biventricular dysfunction. Circulation 1985; 72(suppl III): 411.

101. Shenker Y, Sider RS, Ostafin EA, Grekin RJ - Plasma levels of immunoreactive atrial natriuretic factor in healthy subjects and in patients with edema. J Clin Invest 1985; 76: 1684-8.

102. Burnett JC, Kao PC, Hu C, et al - Atrial natriuretic peptide elevation in congestive heart failure in the human. Science 1986; 231: 1145-9.

103. Gottlieb SS, Kukin ML, Ahern D, et al - Prognostic importance of atrial natriuretic peptide in patients with chronic heart failure. J Am Coll Cardiol 1989; $13: 1534-8$.

104. Hall C, Rouleau JL, Moye L, et al - N-terminal pro-atrial natriuretic factor. An independent predictor of long-term prognosis after myocardial infarction. Circulation 1994; 89: 1934-8.

105. Sudoh T, Kangawa K, Minamino N, Matsuo H - A new natriuretic peptide in porcine brain. Nature 1988; 332: 78-81

106. Kambayashi Y, Nakao K, Kukoyama M, et al - Isolation and sequence determina- 
tion of human brain natriuretic peptide in human atrium. FEBS Lett 1990; 359: 341-5.

107. Mukoyama M, Nakao K, Hosoda K, et al - Brain natriuretic peptide as a nove cardiac hormone in humans: evidence for an exquisite dual natriuretic peptide system, atrial natriuretic peptide and brain natriuretic peptide. J Clin Invest 1991; 87: 1402-12.

108. Hasegawa K, Fujiwara H, Doyama K, et al - Ventricular expression of brain natriuretic peptides in dilated cardiomyopathy: an immunohistochemical study of the endomyocardial biopsy specimens using specific monoclonal antibodies. Am J Pathol 1993; 142: 107-16.

109. Yoshimura M, Yasue H, Morita E, et al - Hemodynamic, renal, and hormonal responses to brain natriuretic peptide infusion in patients with congestive heart failure. Circulation 1991; 84: 1581-8.

110. McDonagh TA, Cunningham AD, Morrison CE, Dargie HJ - Natriuretic paptides, left ventricular dysfunction and mortality: a population-based study. J Cardiac Fail 1998; 4(suppl 1): 51.

111. Stanek B, Punzengruber C, Silberbauer K - Increase in bicycloprostaglandin E metabolite in congestive heart failure in response to captopril. Clin Cardiol 1989; 12: 97-102.

112. Puzengruber C, Stanek B, Sinzinger H, Silberbauer K - Bicyclo-prostaglandin $\mathrm{E}_{2}$ metabolite in congestive heart failure and relation to vasoconstrictor neurohumoral principles. Am J Cardiol 1986; 57: 619-23.

113. Yanagisawa M, Kurihara H, Kimura S, et al - A novel potent vasoconstrictor peptide produced by vascular endothelial cells. Nature 1988; 332: 411-7.

114. Hiroe M, Hirata Y, Fujita N, et al - Plasma endothelin 1 levels in idiopathic dilated cardiomyopathy. Am J Cardiol 1991; 68: 1114-8.

115. Lerman A, Kubo SH, Tschumperlin LK, Burnett JC - Plasma endothelin concentrations in humans with end-stage heart failure and after heart transplantation. J Am Coll Cardiol 1992; 20: 849-54.

116. Wei C-M, Lerman A, Rodeheffer RJ, et al - Endothelin in human congestive heart failure. Circulation 1994; 89: 1580-5.

117. Cody RJ, Haas GJ, Binkley PF, Capers Q, Kelley R - Plasma endothelin correlates with the extent of pulmonary hypertension in patients with chronic congestive heart failure. Circulation 1992; 85: 504-8

118. Pacher R, Stanek B, Hülsmann M, et al - Prognostic impact of big endothelin-1 plasma concentrations compared with invasive hemodynamic evaluation in severe heart failure. J Am Coll Cardiol 1996; 27: 633-41.

119. Wada A, Tsutamoto T, Fukai D, et al - Comparison of the effects of selective endothelin ETa and ETb receptor antagonists in congestive heart failure. J Am Coll Cardiol 1997; 30: 1385-92.

120. Colucci WS, Braunwald E - Pathophysiology of heart failure. In: Braunwald E Heart Disease: A Textbook of Cardiovascular Medicine. $5^{\mathrm{a}}$ edição. Philadelphia: WB Saunders Company, 1997: 394.

121. Levine B, Kalman J, Mayer L, Fillit HM, Packer M - Elevated circulating levels of tumor necrosis factor in severe chronic heart failure. N Engl J Med 1990; 323 : 236-41.

122. Thaik CM, Calderone A, Takahashi N, Colucci WS - Interleuken-1 beta modulates the growth and phenotype of neonatal rat cardiac myocytes. J Clin Invest 1995; 96: 1093-7.

123. Ghali JK, Kadakia S, Cooper R, Ferlinz J - Precipitating factors leading to decompensation of heart failure: traits among urban blacks. Arch Intern Med 1988; 148: 2013-6.

124. Hamilton MA, Stevenson LW, Luu M, et al - Altered thyroid hormone metabolism in advanced heart failure. J Am Coll Cardiol 1990; 16: 91-5.

125. Chakko S, de Nadena E, Kessler K, Myerburg R - Ventricular arrhythmias in congestive heart failure. Clin Cardiol 1989; 12: 525-9.

126. Gilman JK, Jalal S, Naccarelli GV - Predicting and preventing sudden death from cardiac causes. Circulation 1994; 90: 1083-7.

127. Hallstrom AL, Pratt CM, Greene HL, et al - Relations between heart failure, ejection fraction, arrhythmia supression and mortality: analysis of the Cardiac Arrhythmia Supression Trial (CAST). J Am Coll Cardiol 1995; 25: 1250-5.

128. Echt DS, Leibson PR, Mitchell LB, et al - Mortality and morbidity in patients receiving encainide, flecainide, or placebo. The Cardiac Arrhythmia Supression Trial (CAST). N Engl J Med 1991; 324: 781-8.

129. Maggioni AP, Zuanetti G, Franzosi G, et al - Prevalence and prognostic significance of ventricular arrhythmias after acute myocardial infarction in the fibrinolytic era. Circulation 1993; 87: 312-22.

130. Bigger JT Jr - Why patients with heart failure die: Arrhythmias and sudden cardiac death. Circulation 1987; 75(suppl IV): IV-28.
131. Doval HC, Nul DR, Grancelli HO, et al - Nonsustained ventricular tachycardia in severe heart failure: independent marker of increased mortality due to sudden death. GESICA-GEMA investigators. Circulation 1996; 94: 3198-203.

132. Keogh AM, Baron Dw, Hickie JB - Prognostic guidelines in patients with dilated or ischemic dilated cardiomyopathy assessed for cardiac transplantation. Am J Cardiol 1990; 65: 903-8.

133. Constantin L, Martins JB, Kienzle MG, et al - Induced sustained ventricular tachycardia in nonischemic dilated cardiomyopathy: dependence on clinica presentation and response to antiarrhythmic agents. PACE 1989; 12: 776-80.

134. Gill JS, Camm JA - Management of arrhythmias in patients with heart failure evaluation and treatment with drugs and devices. In: Poole-Wilson PA, Colucci WS, Massie BM, Chattenjee K, Coats AJS, eds - Heart Failure. New York: Churchill Livingstone, 1997: 747-58.

135. Middlekauff HR, Stevenson WG, Stevenson LW - Prognostic significance of atrial fibrilation in advanced heart failure: a study of 390 patients. Circulation 1991; 84: 40

136. Carson PE, Johnson GR, Dunkman B, et al - The influence of atrial fibrillation on prognosis in mild to moderate heart failurre. Circulation 1993; 87(suppl VI): 102.

137. Kowey PR, Taylor JE, Rials SJ - Does programmed stimulation really help in the evaluation of patients with nonsustained ventricular tachycardia? Results of a meta-analysis. Am Heart J 1992; 123: 481-5.

138. McClements TA, Adgey AAJ - Value of signal averaged electrocardiography, radionuclaide, Holter monitoring and clinical variables for prediction of arrhythmic events in survivors of acute myocardial infarction in the trombolytic era. J Am Coll Cardiol 1993; 21: 1419-27.

139. Buckingham TA, Ghosh S, Homan SM, et al - Independent value of signal averaged electrocardiography and left ventricular function in identifying patients with sustained ventricular tachycardia with coronary artery disease. Am J Cardiol 1987; 159: 568-71.

140. Kuchar DL, Thorburn CW, Sammel NL - Prediction of serious arrhythmic events after myocardial infarction: signal averaged electrocardiogram, Holter monitoring and radionuclide ventriculography. J Am Coll Cardiol 1987; 9: 531-8.

141. Farrel TG, Bashir Y, Cripps T, et al - Risk stratification for arrhythmic events in postinfarction patients based on heart rate variability, ambulatory electrocardiographic variables and the signal averaged electrocardiogram. J Am Coll Cardiol 1991; 18: 687-97.

142. Denereaz D,Zimmerman M, Adamec R - Significance of ventricular late potentials in non-ischemic dilated cardiomyopathy. Eur Heart J 1992; 14: 895-901.

143. Meinertz T, Treese N, Kasper W, et al - Determinants of prognosis in idiopathic dilated cardiomyopathy. Am J Cardiol 1985; 56: 337-41.

144. Mancini DM, Wong KL, Simson MB - Prognostic value of an abnormal signalaveraged electrocardiogram in patients with non-ischemic congestive cardiomyopathy. Circulation 1993; 87: 1083-92.

145. Yi G, Keeling PJ, Goldman JF, et al - Prognostic significance of spectral turbulance analysis of the signal averaged electrocardiogram in patients with idiopathic dilated cardiomyopathy. Am J Cardiol 1995; 75: 494-8.

146. Barr CS, Naas A, Freeman M, Lang CC, Struthers AD - QT dispersion and sudden unexpected death in chronic heart failure. Lancet 1994; 343: 327-9.

147. Pinsky DJ, Sciacca RR, Steinberg JS - QT dispersion as a marker of risk in patients awaiting heart transplantation. J Am Coll Cardiol 1997; 29: 1576-84.

148. Nolan J, Flapan AD, Capewell S, MacDonald TM, Neilson JM, Ewing DJ Decreased cardiac parasympathetic activity in chronic heart failure and its relation to left ventricular function. Br Heart J 1992; 67: 482-5.

149. Mortara A, La Rovere MT, Signorini MG, et al - Can power spectral analysis of heart rate variability identify a high risk subgroup of congestive heart failure patients with excessive sympathetic activation? A pilot study before and after transplantation. Br Heart J 1994; 71: 422-30.

150. Fei L, Keeling PJ, Gill JS, et al - Heart rate variability and its relation to ventricular arrhythmias in congestive heart failure. Br Heart J 1994; 71: 322-8.

151. Kienzle MG, Ferguson DW, Birkett CL, Myers GA, Berg WJ, Mariano DJ Clinical, hemodynamic and sympathetic neural correlates of heart rate variability in congestive heart failure. Am J Cardiol 1992; 69: 761-7.

152. Binder T, Frey B, Porenta G, et al - Prognostic value of heart rate variability in patients awaiting cardiac transplantation. PACE 1992; 15: 2215-20.

153. Ponikowski P, Anker SD, Chua TP, et al - Depressed heart rate variability as an independent predictor of death in chronic congestive heart failure secondary to ischemic or idiopathic dilated cardiomyopathy. Am J Cardiol 1997; 79: 1645-50.

154. Fauchier L, Babuty D, Cosnay P, Autret ML, Fauchier JP - Heart rate variability in idiopathic dilated cardiomyopathy: characteristics and prognostic value. $\mathrm{J}$ Am Coll Cardiol 1997; 30: 1009-14. 